\title{
Transnational and Counternational Queer Agencies in Lusophone Cultures: Introduction
}

\author{
ANNA M. KLOBUCKA \\ University of Massachusetts Dartmouth
}

CÉSAR BRAGA-PINTO

Northwestern University

This special issue of the Journal of Lusophone Studies was devised with the aim of addressing issues of (nonnormative) gender and (queer) sexuality in relation to travel, translation, transnational friendships and relationships, posturing and imitation, contagion, promiscuity, and other related themes across the spectrum of modern Luso-Afro-Brazilian literatures and cultures from the nineteenth century onward. Collectively, the editors and contributors are particularly interested in considering the ways in which queer subjectivities and agencies have counteracted triumphant versions of the nation and nationalism that seek to foreclose any alternatives to patriarchal and heteronormative fictions of progress and homogeneous identity. Such counternational alternatives may be articulated in minor gestures (possibly "inauthentic" or derivative) and in failures and shortcomings rather than successes and achievements. Beyond the nation, we also intend to encourage queering questionings of the transnational ideal of "Lusofonia" and the extent to which its official version reproduces the national, or, conversely, its informal reality opens up space for nonnormative encounters, exchanges, or performances of identity. And beyond Lusofonia, we seek to stimulate reflections on transnational travels of queer theory and the resistances and (productive) corruptions generated by global dissemination of dominant theoretical paradigms. 
Queer studies have developed unevenly and discontinuously across the heterogenous landscape of literary and cultural productions, traditions, and histories of the Portuguese-speaking world. A comprehensive history of representations of nonnormative sexualities in Lusophone literatures and cultures is still lacking. With few, though notable, exceptions, most studies of queer authors and the (less common) theorizations of queer literary production are scattered in journals or edited volumes; since the pioneering publication of Gasparino da Matta's Histórias do amor maldito (1967), anthologies of queer writing (Honório; Ruffato; Machado e Moura; Antologia Trans; Sousa; Bessa; Mello) have not aimed to be exhaustive, either chronologically or geographically. In the case of Brazil, one of the earliest critical essays that may retrospectively be identified as a "queer" reading was Silviano Santiago's "O Ateneu: contradições e perquirições" (1968), whose interpretation ran against the grain of the heteronormative reading frameworks traditionally applied to Raul Pompeia's novel and the figure of its author. But it was only from the 1980s onward that a number of studies on literary representations of homosexuality and homoeroticism began to appear, at first mainly in Brazil and often produced by anthropologists, historians, sociologists, or others working outside of the sphere of literary studies (Fry; Mott; Trevisan; Green; Miskolci), with a notable emphasis on nineteenth-century Luso-Brazilian naturalism, particularly Adolfo Caminha's Bom crioulo and (later) Abel Botelho's O Barão de Lavos (Howes 2001, 2002). In Portugal, initial studies of queer agencies and representations in Portuguese literature and culture were largely produced outside of academia (Pitta; Almeida) or featured limited participation from literary scholars, as in the case of the pioneering anthology Indisciplinar a teoria, edited by António Fernando Cascais.

In the last two decades, literary scholars have joined the conversation more robustly, beginning, in Brazil, with Leonardo Mendes's study O retrato do imperador: negociação, sexualidade e romance naturalista no Brasil (2000). Many of the books and theses on nonnormative sexualities in Lusophone literatures have revolved around individual - and disproportionately maleauthors such as Silviano Santiago and Caio Fernando Abreu (Posso), Glauco Mattoso (Butterman), or António Botto (Klobucka). In addition, several historical overviews and collective volumes have been published since the beginning of this century, among them José Luiz Foureaux's Literatura $e$ 
homoerotismo: uma introdução (2002); José Carlos Barcelos's Literatura e homoerotismo em questão (2006); Ricardo Thomé's Eros proibido: as ideologias em torno da questão homoerótica na literatura brasileira (2009); Paulo Drummond Braga's Filhas de Safo: uma história da homossexualidade feminina em Portugal (2011); Fernando Curopos's Queer(s) périphérique(s): représentation de l'homosexualité au Portugal (1974-2014) and L'émergence de l'homosexualité dans la littérature portugaise (1875-1915) (2016); and Jorge Vicente Valentim's Corpo no outro corpo: homoerotismo na narrativa portuguesa contemporânea (2017). In Brazil, fundamental to the dissemination and retheorization of sexuality and queer studies have been the works of Denilson Lopes, particularly his $O$ homem que amava rapazes (2002). The volume Retratos do Brasil homossexual: fronteiras, subjetividades, desejos (2010), a collection of papers presented at the IV Conference of the Associação Brasileira de Homocultura, contains nine essays under the heading "Homocultura e literatura." Beyond literary studies, film and theater have also been the object of several volumes published over the past two decades (Moreno; Louro; Albuquerque). Studies engaging with issues of queer sexuality in Lusophone African cultural and literary productions have remained quite scarce, and for the most part confined to article form or integrated within more broadly designed book-length projects (Owen and Rothwell; Jones).

Until relatively recently, fora for transatlantic dialogue on Lusophone queer literatures and theories were still rare. The first attempt to produce such a forum was the landmark Lusosex: Gender and Sexuality in the Portuguese-Speaking World (2002), edited by Susan Canty Quinlan and Fernando Arenas. The editors' introduction to that volume recognizes the constitutive unease that infused their project, as it does our own: "There are unavoidable paradoxes in working simultaneously with former colonizing powers and nations that are the result of colonial processes" (xxi). And yet, Quinlan and Arenas insist on underscoring "the productive tension that derives from the usage of the term luso, as we add to it the charged signifier sex" (xxi), expressing the conviction-which we share - that appropriative and subversive engagements with legacies of the Portuguese colonialism and its aftermath have much to gain from being brought together in a global comparative perspective. Although "Lusofonia" remains a deeply contested geopolitical concept, the intersection of the Lusophone (dis)continuum with queer literary studies (and activisms) may open, and indeed 
has opened, promising possibilities for imagining new configurations of sexuality beyond those codified in canonical historical narratives and framed by national hegemonies. In fact, several recent collective initiatives, comprising international conferences and resulting publications, have borne out this dynamically constructive potential, as illustrated by two special journal issues published in 2018: São Paulo-based Via Atlântica's "Queerizar o cânone lusoafro-brasileiro" and Porto-based Cadernos de literatura comparada's "Intersexualidades em questão."

This special issue of the Journal of Lusophone Studies likewise originated in the context of a conference, a three-panel seminar we co-organized for the 2017 meeting of the American Comparative Studies Association in Utrecht, Netherlands, a fitting location given that our project aims to contribute to developing and shaping directions for queer studies of Portuguese-language literatures and cultures by emphasizing border-crossing dialogues and engagements both within and beyond Lusofonia. Rather than focus on spatial mapping, however, we have chosen to organize the issue chronologically, as if it were an outline for a historical survey or genealogy of queer Lusophone textualities. At the same time, each essay breaks with any properly disciplined sense of temporal progression, and may indeed dialogue with its companion pieces transversally by proposing cognate forms of transnational and counternational queer agencies. The issue of queer exile, for example, is at the center of Severino Albuquerque's piece on the Argentinian Tulio Carella and Brazilian Hermínio Borba Filho. For Albuquerque, the diary kept by Carella while he worked as a theater professor in Recife in the early 1960s and its translation and adaptation by Borba Filho become a point of departure for a rich discussion of the interlocking processes of (queer) transnationality, translationality, and appropriation. The exilic condition concerns also Carlos Cortez Minchillo, who, through admirable archival work, recovers the fascinating writings and trajectory of the Russian emigré poet Valério Pereliéchin (1913-1992), who moved to Brazil in the 1950s after having lived for thirty years in China, and who wrote in Russian, English, and Portuguese, but embraced a Brazilian identity even when publishing in English. Two other contributors show how fin-de-siècle literature and Decadent aesthetics in general have been instrumental in shaping queer positioning on the margins of national identities. In Anna Klobucka's essay on Visconde de Vila-Moura's Nova Safo (1912), this 
largely neglected text, traditionally labeled as Portugal's only Decadent novel, is redescribed as a countercultural scrapbook of queer feeling replete with surprising and spellbinding gestures of cosmopolitan transitive embodiment. For his part, through the figure of the queer suicidal, César Braga-Pinto utilizes Decadence as a means to challenge the genealogical, reproductive model of national literary history and move beyond periodizations, in the process recovering the forgotten playwright Roberto Gomes (whose writings may well be unreadable today but who nonetheless plays a key role in the alternative historical narrative Braga-Pinto construes). In close proximity to these approaches, albeit in reference to a much-studied text by a canonical author, Fernando Beleza's reading of Mário de Sá-Carneiro's A confissão de Lúcio examines the relationship between transnational mobility and sexual dissidence in a theoretical framework that draws on the Freudian concept of the uncanny to ultimately argue for Sá-Carneiro's performative destabilization of his identity as a national author.

As the image of the nation fades into the background, other local figures and texts emerge from its margins and contours. From different perspectives, both Vagner Camilo and Carolina Castellanos's essays redraw the margins of Brazilian literary history by taking seriously bodies of writing that traditional literary criticism has considered unreadable or unworthy of being studied. Camilo complicates national historiography as he rescues a lyric poem by the baiano Junqueira Freyre to show how the Romantic poet breaks with the satiric (and potentially homophobic) style of his contemporaries Laurindo Barreto and Moniz Barreto. Castellanos, in her turn, claims that the 1980 quasi-pornographic novel Eu sou uma lésbica, by the bestselling writer Cassandra Rios, naturalizes female homosexuality even as it can also be said, ultimately, to reinforce class and racial stereotypes.

The centrality, homogeneity, and imagined virility of the nation are further displaced by the examinations of performances of gender and nonnormative sexuality in the essays by James Hodgson, Alejandro Castro, Daniel da Silva, and António Fernando Cascais. Cascais reads a number of Portuguese literary and critical narratives that deal with masculinity and sex among Portuguese troops during the colonial wars of independence (1961-1974) to show how, rather than confirming the virility of the warrior and his nation throught the emergence of the "new man," the experience of war provoked a traumatic crisis 
of masculinity that concerned not only gender identities but also the entire political regime and its colonial project. Silva's subtle dissection of Ney Matogrosso's recording of "Mãe preta (Barco negro)" (1975), which returned to its Brazilian origins a fado made famous by Amália Rodrigues, locates in Ney's transgender voice performance and album artwork a convergence of queer, indigenous, and Afro-Brazilian elements that reembody the "black mother" figure, central to foundational narratives of Brazilian society, in a musical shape that unsettles both the Freyrean mythology of race relations and Portuguese nationalist tropes. An unsettling of established models of heteropatriarchal community and relationality is also the leading theme of Hodgson's attentive analysis of $O$ menino e o vento (The boy and the wind), the 1968 work of Argentinian-Brazilian filmmaker Carlos Hugo Christensen, in which, as Hodgson argues with recourse to Leo Bersani's Homos, a utopian refashioning of homosexuality presents an alternative to the homophobic and hierarchical social organization represented in the film. Lastly, Alejandro Castro's reading of "El queso del quechua," the Spanish-language translation, published in Argentina, of Glauco Mattoso's short story "O quitute do quíchua," through a theoretical prism that blends fetishism, anthropophagy, blindness, coprophagy, and sadomasochism, connects (despite its distinct critical idiom) to both Albuquerque's and Hodgson's explorations of Brazilian-Argentinian exchanges in the realm of queer aesthetics and relationality.

A few regrets remain to be registered. To a significant extent, this issue has come to mirror the imbalances and hierarchies of interest and engagement that structure the burgeoning field of Lusophone queer studies at large. Despite the editors' efforts, no contribution addresses African literary and cultural productions in Portuguese, and the roster of authors and artists discussed across the issue is overwhelmingly male. Although many critical affinities and common themes do emerge from the ensemble, for the most part it would be difficult to identify among the contributors a shared epistemological ground and a set of foundational assumptions and defined approaches comparable to those that structure the field of Anglo-American queer theory and criticism. Whether the future emergence of such a culturally inflected shared environment can be expected or should be desired is a question that exceeds the purview of this introduction; nonetheless, we hope to have advanced, in some small way, the 
connectedness among individual and collective agencies the contributions to this issue explore and reflect.

\section{Works Cited}

Albuquerque, Severino. Tentative Transgressions: Homosexuality, AIDS, and the Theater in Brazil. U of Wisconsin P, 2004.

Almeida, São José. Homossexuais no Estado Novo. Sextante, 2010.

Antologia trans: 30 poetas trans, travestis e não-binários. Trans-formação, 2017.

Bessa, Marcelo Secron. Histórias positivas: a literatura (des)construindo a AIDS. Record, 1997.

—. Os perigosos: autobiografias e AIDS. Aeroplano, 2002.

Braga, Paulo Drummond. Filhas de Safo: uma história da homossexualidade feminina em Portugal. Texto, 2011.

Butterman, Stephen. Perversions on Parade: Brazilian Literature of Transgression and Postmodern Anti-Aesthetics in Glauco Mattoso. San Diego State UP, 2005.

Campos, Maria Consuelo Cunha. De Frankenstein ao transgênero. Ágora da Ilha, 2001.

Cascais, António Fernando, ed. Indisciplinar a teoria: estudos gays, lésbicos e queer. Fenda, 2004.

Costa, Horácio, et al., ed. Retratos do Brasil homossexual: fronteiras, subjetividades e desejos. U de São Paulo, 2010.

Curopos, Fernando. Queer(s) périphérique(s): représentation de l'homosexualité au Portugal (1974-2014). L'Harmattan, 2016.

—. L'émergence de l'homosexualité dans la littérature portugaise (1875-1915). L'Harmattan, 2016.

Damata, Gasparino, Octávio de Freitas e Aníbal Monteiro Machado. Histórias do amor maldito, Record, 1967.

Fry, Peter. "Léonie, Pombinha, Amaro e Aleixo: prostitução, homossexualidade e raça em dois romances naturalistas." Caminhos cruzados: linguagem, antropologia e ciências naturais, Brasiliense, 1982, pp. 33-51.

Green, James. Beyond Carnival: Male Homosexuality in Twentieth-Century Brazil. U of Chicago P, 1999. 
Honório, José Carlos. O amor com olhos de adeus: antologia do conto gay brasileiro. Transviatta, 1995.

Howes, Robert. "Race and Transgressive Sexuality in Adolfo Caminha's BomCrioulo." Luso-Brazilian Review, vol. 38, no. 1, 2001, pp. 41-62.

-. "Concerning the Eccentricities of the Marquis of Valada: Politics, Culture and Homosexuality in Fin-de-Siècle Portugal." Sexualities, vol. 5, no. 1, 2002, pp. 25-49.

Inácio, Emerson, et al., eds. "Intersexualidades em questão." Cadernos de literatura comparada, no. 39, 2018, pp. 5-240.

Jones, Eleanor. Battleground Bodies: Gender and Sexuality in Mozambican Literature. Peter Lang, 2017.

Klobucka, Anna M. O mundo gay de António Botto. Sistema Solar, 2018.

Lopes, Denilson. O homem que amava rapazes e outros ensaios. Aeroplano, 2002.

Louro, Guacira Lopes. Flor de açafrão: takes, cuts, close-ups. Autêntica, 2017.

- Um corpo estranho: ensaios sobre sexualidade e teoria queer. Autêntica, 2018.

Machado, Amanda, and Maria Moura. Poesia gay brasileira: antologia. Machado e Amarelo Grão, 2017.

Mello, Ramon Nunes. Tente entender o que quero dizer. Bazar do Tempo, 2018.

Miskolci, Richard. O desejo da nação: masculinidade e branquitude no Brasil de fins do XIX. Annablume, 2013.

Moreno, Antonio. $O$ personagem homosexual no cinema brasileiro. Eduff/Funarte, 2001.

Mott, Luiz. O lesbianismo no Brasil. Mercado Aberto, 1987.

Owen, Hilary, and Phillip Rothwell, eds. Sexual/Textual Empires: Gender and Marginality in Lusophone African Literature. U of Bristol, 2004.

Pitta, Eduardo. Fractura: a condição homossexual na literatura portuguesa contemporânea. Angelus Novus, 2003.

Posso, Karl. Artful Seduction: Homosexuality and the Problematics of Exile. Legenda, 2004.

Lentina, Alda, et al., eds. "Queerizar o cânone luso-afro-brasileiro." Via Atlântica, no. 33, 2018, pp. 21-405.

Ruffato, Luís, ed. Entre nós: contos sobre a homossexualidade. Língua Geral, 2007. 
Santiago, Silviano. "O Ateneu: contradições e perquirições." Uma literatura nos trópicos, Brasiliense, 2000, pp. 66-102.

Sousa, Isidro, ed. 1. ${ }^{a}$ antologia de literatura homoerótica portuguesa. Korpus \& Opus Gay, 2001.

Souza Jr., José Luiz Foureaux, ed. Literatura e homoerotismo: uma introdução. Scortecci, 2002.

Thomé, Ricardo. Eros proibido: as ideologias em torno da questão homoerótica na literatura brasileira. Nova Razão Cultural, 2009.

Trevisan, João Silvério. Devassos no paraíso: a homossexualidade no Brasil, da colônia à atualidade. Record, 2000. 